- Central and peninsular India exhibited increasing frequency of heavy rainfall events during pre-monsoon and monsoon.

- Study between two episodes (1951-1980 to 19812010) suggests that peninsular India, Gujarat and states of the NE are warming more compared to the northern states (@0.01 ${ }^{\circ} \mathrm{C} /$ year), while the dry farming tracts of the country are experiencing a decreasing trend in the rainfall activity.

In the present study, the observed climate change at various agcroclimatic zones in the northeastern states, Gujarat, hilly areas of the country, and central and peninsular exhibits significant increasing/decreasing trends in weather parameters like temperature, rainfall, heavy rainfall and rainy days. This definitely indicates change in climate from pre-90 to post-90s. Thus, all these changes of climatic parameters would have a definite impact on the classification of agroclimatic zones. Therefore, we must reconsider the classification of agroclimatic zones in India under the scenario of observed climate change in the country.

1. ICAR, agroclimatic zone specific research. In Indian Perspectives under NARP, Indian Council of Agricultural Research, New Delhi, 1991.

2. Kothawale, D. R., Munot, A. A. and Krishna Kumar, K., Surface air temperature variability over India during 1901-2007 and its association with ENSO. Climate Res., 2010, 42, 89-104; doi:10.3354/ cr00857.

3. Srivastava, A. K., Kothawale, D. R. and Rajeevan, M. N., Variability and long-term changes in surface air temperatures over the Indian subcontinent. In Observed Climate Variability and Change over the Indian Region, Springer, Singapore, 22 November 2016, 2017, 1st edn, pp. 17-36.

4. Naidu, C. V., Srinivasa Rao, B. R. and Bhaskar Rao, D. V., Climatic trends and periodicities of annual rainfall over India. Meteorol. Appl., 1999, 6, 395-404; doi:10.1017/S1350482799001358.

5. Chung, C. E. and Ramanathan, V., Weakening of North Indian SST gradients and the monsoon rainfall in India and the Sahel. J. Climate, 2006, 19, 2036-2045.

6. Parthasarathy, B. and Dhar, O. N., Climate fluctuations over Indian region-rainfall: a review. Research Report No. RR-025. Indian Institute of Tropical Meteorology, Pune, 1978, p. 14.

7. Rupa Kumar, K., Pant, G. B., Parthasarathy, B. and Sontakke, N. A., Spatial and sub-seasonal patterns of the long-term trends of Indian summer monsoon rainfall. Int. J. Climatol., 1992, 12, 257-268.

8. Guhathakurta, P. and Rajeevan, M., Trends in rainfall pattern over India. Int. J. Climatol., 2008, 28, 1453-1469.

9. Vijay Kumar, S. and Jain, K., Trends in rainfall amount and number of rainy days in river basins of India (1951-2004). Hydrol. Res., 2011, 42(4), 290-306; doi:10.2166/nh.2011.067.

ACKNOWLEDGEMENTS. We thank Dr S. Khedikar, Smt Gracy John, Smt V. R. Choudhary, Smt Nivedita Tidke, Smt B. S. Kurtkoti, Smt Shweta Mukim and Shri Gaurav Sharma from Agricultural Meteorology Division, India Meteorological Department, for help during data analysis.

Received 6 April 2018; accepted 21 May 2019

doi: $10.18520 / \mathrm{cs} / \mathrm{v} 117 / \mathrm{i} 3 / 480-486$

\section{Soybean methylation analysis during strontium stress using methylation-sensitive amplified polymorphism}

\author{
Qingyuan $\mathrm{He}^{*}$, Zhengpeng Li, Yingjie Shu, \\ Songhua Wang and Shoucheng Huang \\ Life Science College of Anhui Science and Technology University, \\ Fengyang, Auhui 233100, China
}

The effect of strontium stress on the pattern and degree of DNA methylation in soybean seedlings was analysed using the methylation-sensitive amplified polymorphism (MSAP) method. The growth traits were inhibited by $\mathrm{SrCl}_{2}$ treatments. A total of 167 loci were determined and evaluated for DNA methylation after different treatments. The level of cytosine methylation initially decreased and then increased with increasing $\mathrm{Sr}$ concentration. Methylation was lowest after $10 \mathrm{mmol} / \mathrm{l} \mathrm{SrCl}_{2}$ treatment. Strontium stress resulted in a $57.48 \%$ alteration of DNA methylation patterns in $5^{\prime}$-CCGG-3' loci. The pattern variation initially decreased and then increased along with increasing strontium concentration. There was a positive correlation between the total methylation and full methylation induced by strontium stress, and weight and length of shoots and roots in soybean. Overall, the changes in the pattern and degree of methylation may be a key regulatory mechanism for soybean adaptation to strontium.

Keywords: Methylation/demethylation, polymorphism, soybean, strontium stress.

STRONTIUM ( $\mathrm{Sr}$ ) is an essential microelement for the human body that plays an important role in bone formation and vascular endothelial cell proliferation ${ }^{1,2}$. However, a variety of diseases may be caused by elevated strontium levels in drinking water and the food chain. Strontium can be deposited in human bone tissue and remain there for many years. It can cause acute and chronic injury to nerve regulation function and cardiovascular function, and can also cause immune dysfunction ${ }^{3}$. Strontium has been widely used in kinescope, fireworks and radiotherapy, as well as in the pharmaceutical and nuclear industries ${ }^{4}$. Increasing amounts of strontium are being released into the soil, water and environment.

To overcome this problem, there is an effective measure to store strontium into the plant. The method is a clean, cost-effective and feasible technology. Previous studies have indicated that low doses of strontium in the environment promote $\mathrm{CO}_{2}$-fixation capacity of plants, thus accelerating the electron transport of photosystem II complex (PS II), water photolysis and oxygen evolution,

*For correspondence. (e-mail: heqingyuan1@163.com) 
but large amounts of stable strontium decrease the $\mathrm{CO}_{2}$ fixation capacity and oxygen evolution ${ }^{5}$. The antioxidant enzyme activity of plants is affected by environmental stress $^{6}$. Changes in DNA methylation are important factors for adaptation to biotic/abiotic stress, and methylation leads to the regulation of gene expression and various physiological mechanisms ${ }^{7,8}$ without changing the genomic sequence 9 .

DNA methylation/demethylation plays an important function in a diverse array of cellular activities, such as gene transcription, gene regulation, genomic imprinting, gene silencing, chromatin modification, DNA replication timing, dosage compensation and disease resistance in plants ${ }^{10}$. Methylation generally represses transcription and demethylation prompts gene expression ${ }^{11}$. Transposons are directly regulated by methylation and may play a key function in the plant response to stress ${ }^{12}$. Methylation leads to gene silencing and demethylation increases the corresponding gene expression level ${ }^{13}$.

In plants, DNA methylation mainly occurs at the position of cytosine occurring at three sites: $\mathrm{CpG}, \mathrm{CpHG}$ and $\mathrm{CpHH}$ sites ( $\mathrm{H}$ represents $\mathrm{C}, \mathrm{T}$ or $\mathrm{A})$. There are many methods to detect DNA methylation ${ }^{14}$, including methylation-sensitive amplified polymorphism (MSAP), bisulphite sequencing, methylation-specific PCR, high resolution melting and pyrosequencing. Among these, MSAP is the most convenient and rapid detection method ${ }^{15}$. The technique has been extensively utilized in environmental stress because of its many advantages, such as convenient primer design without prior knowledge of sequence information, the high number of available polymorphic loci, and easy and economical operation ${ }^{11,16-18}$.

MspI and HpaII are methylation-sensitive restriction endonucleases that recognize the same DNA sequence ( $5^{\prime}$-CCGG-3'); however, they can distinguish differential nucleotide methylation patterns. MspI is inactive when there is lateral methylation of cytosine $\left(5^{\prime}-5 \mathrm{mCCGG}-3^{\prime}\right)$, but digests the sequence when there is interior methylation $\left(5^{\prime}-\mathrm{C} 5 \mathrm{mCGG}-3^{\prime}\right)$. However, HpaII is sensitive to two types of cytosine methylation and cannot digest sites containing $5^{\prime}$-mCCGG-3', 5'-CmCGG-3', or 5'-mCmCGG-3' (ref. 19).

Soybean has become the largest cultivated legume crop, providing $30 \%$ of edible oil and about $70 \%$ of dietary protein ${ }^{20}$. Within a certain concentration range, the stress of strontium ions leads to increased levels of phytoestrogens (coumestans, prenylflavonoids and isoflavones) in soybeans ${ }^{21}$. However, high concentration of strontium leads to yield loss and death of the plant. Methylation/demethylation may be one of the reasons for these phenomena. However, there has been no report on the study of patterns and degree of DNA methylation/ demethylation induced by strontium stress in soybean. In order to study changes in soybean methylation due to strontium stress, the patterns and degree of seedling genomic methylation were detected and compared after treatment with different strontium concentrations using the MSAP method. These results provide a preliminary global insight into the genomic methylation of soybean under strontium stress.

The soybean variety 'Nannong $1138-2$ ' is an excellent parent and an important cultivar of breeding in the middle and lower reaches of Yangze River in China ${ }^{22}$. All seeds were surface-sterilized with $0.1 \% \mathrm{HgCl}_{2}$ for $8 \mathrm{~min}$ and rinsed clean using sterilized water. Then they were germinated in plastic pots containing washed sand under conditions of natural light in a greenhouse. The uniform seedlings were selected and transferred to $1 / 2$ Hoagland nutrient solution ( $\mathrm{pH}$ 5.8). At the $\mathrm{V} 2$ growth stage of soybean $^{23}$, the seedlings were treated with $1 / 2$ Hoagland solution containing six different $\mathrm{SrCl}_{2}$ concentrations $(0$, $1,5,10,20$ and $40 \mathrm{mmol} / \mathrm{l})$ for 7 days with three replicates for each treatment, one pot per replicate and five plants per pot.

After treatment, the root and stem lengths were measured considering the cotyledon node as the dividing point. The dry and fresh weights of the aboveground parts and roots were determined and the root/shoot ratio was calculated.

The total DNA was isolated from fresh leaves using the slightly improved CTAB method ${ }^{24}$. The MSAP analysis was performed as previously described ${ }^{25}$. Table 1 lists the adapters, primers of pre-amplification and selective amplification. The total DNA was double digested at $37^{\circ} \mathrm{C}$ with $M s p \mathrm{I} / E c o \mathrm{RI}$ or $H p a \mathrm{II} / E c o \mathrm{RI}$ (Fermentas) for $4 \mathrm{~h}$. Each sample contained approximately $500 \mathrm{ng}$ of total DNA, $10 \mathrm{U}$ MspI or HpaII, $10 \mathrm{U}$ EcoRI, $2 \mu \mathrm{l}$ of $10 \times$ T-buffer, and $2 \mu \mathrm{l}$ of $0.1 \%$ BSA (bovine serum albumin) in a $20 \mu \mathrm{l}$ reaction system. The samples were treated for $10 \mathrm{~min}$ at $65^{\circ} \mathrm{C}$ to terminate the enzyme digestion reactions $^{15}$.

A day before the reaction, two EcoRI adapters were mixed and diluted to $5 \mathrm{pmol} / \mu \mathrm{l}$, incubated at $95^{\circ} \mathrm{C}$ for $5 \mathrm{~min}$, and then cooled using an ice bath for $5 \mathrm{~min}$. Two $50 \mathrm{pmol} / \mu \mathrm{l} \mathrm{MspI/HpaII}$ adapters were also treated using the same procedure. The DNA fragments obtained after enzyme digestion were immediately ligated to the adapter in total $20 \mu \mathrm{l}$ of ligation system containing $11 \mu \mathrm{l}$ digested product, $10 \mathrm{pmol}$ EcoRI and $100 \mathrm{pmol}$ MspI/HpaII adapters, $1 \mathrm{U}$ T4 ligase, $2 \mu \mathrm{l}$ T4-buffer, which was incubated overnight (about $12 \mathrm{~h}$ ) at $16^{\circ} \mathrm{C}$. The ligation production was diluted five-fold for subsequent amplification reactions ${ }^{7}$.

The $20 \mu \mathrm{l}$ preamplification reaction contained $4 \mu \mathrm{l}$ of ligation DNA, $3 \mu \mathrm{l}$ of $20 \mathrm{pmol} / 1 E c o \mathrm{RI}+\mathrm{A}$ and $M s p \mathrm{I} /$ HpaII $+\mathrm{O}$ primers, and $10 \mu \mathrm{l}$ of $2 \times$ exTaq polymerase (TakaRa). The reaction protocol consisted of 2 min predenaturation at $95^{\circ} \mathrm{C}, 25$ cycles at $94^{\circ} \mathrm{C}$ for $30 \mathrm{~s}, 55^{\circ} \mathrm{C}$ for $1 \mathrm{~min}, 72^{\circ} \mathrm{C}$ for $1 \mathrm{~min}$ and final extension at $72^{\circ} \mathrm{C}$ for $8 \mathrm{~min}$. The pre-amplification product were diluted tenfold with ultra pure water and utilized as a template for selective amplification reactions. Selective amplification 
Table 1. Sequence of adapters and primers used for methylation-sensitive amplified polymorphism (MSAP) analysis

\begin{tabular}{lcc}
\hline \multirow{2}{*}{ Primer } & \multicolumn{2}{c}{ Sequence } \\
\cline { 2 - 3 } Adapter primer & \multicolumn{1}{c}{ EcoRI $\left(5^{\prime}-3^{\prime}\right)$} & Msp I/HpaII $\left(5^{\prime}-3^{\prime}\right)$ \\
\hline \multirow{2}{*}{ Pre-amplification primer } & CTCGTAGACTGCGTACC & GATCATGAGTCCTGCT \\
Selective amplification primers & AATTGGTACGCAGTCTAC & CGAGCAGGACTCATGA \\
& GACTGCGTACCAATTCA & ATCATGAGTCCTGCTCGG \\
& GACTGCGTACCAATTCAAAG & ATCATGAGTCCTGCTCGGTCT \\
& GACTGCGTACCAATTCAACA & ATCATGAGTCCTGCTCGGTCC \\
& GACTGCGTACCAATTCAACT & ATCATGAGTCCTGCTCGGTTC \\
& GACTGCGTACCAATTCAACC & ATCATGAGTCCTGCTCGGTTG \\
& GACTGCGTACCAATTCAACG & ATCATGAGTCCTGCTCGGTTA \\
& GACTGCGTACCAATTCAAGC & ATCATGAGTCCTGCTCGGTGA \\
& GACTGCGTACCAATTCAAGG & ATCATGAGTCCTGCTCGGTGT \\
\hline
\end{tabular}

used the same PCR reaction system of preamplification with selective amplification primers and preamplification products instead of preamplification primers and ligation DNA respectively. The selective amplification PCR protocol included a denaturation step at $94^{\circ} \mathrm{C}$ for $5 \mathrm{~min}$, $94^{\circ} \mathrm{C}$ for $30 \mathrm{~s}, 65^{\circ} \mathrm{C}$ for $30 \mathrm{~s}$ (dropping $1{ }^{\circ} \mathrm{C}$ per cycle) and $72^{\circ} \mathrm{C}$ for $1 \mathrm{~min}$. This programme was executed with 30 cycles at $94^{\circ} \mathrm{C}$ for $30 \mathrm{~s}, 55^{\circ} \mathrm{C}$ for $30 \mathrm{~s}$ and $72^{\circ} \mathrm{C}$ for $1 \mathrm{~min}$ with a final extension at $72^{\circ} \mathrm{C}$ for $8 \mathrm{~min}$ (ref. 15). The selective amplification products were separated by gel electrophoresis on $8 \%$ PAGE (polyacrylamide gel). The bands were displayed used silver staining.

A score of 1 represents the presence of a band and 0 represents absence of a band in the same locus. The methylation patterns were classified as the following four types according to the results of MSAP detection as follows: (i) Type I - band present for both enzyme reactions $(1,1)$, representing no methylation in CCGG sites. (ii) Type II - band present only for EcoRI/HpaII $(1,0)$, representing the hemi-methylation in 5'-CCGG sites; a DNA strand has methylation, but its complementary strand is not methylated. (iii) Type III - band present only for $E c o R I / M s p I(0,1)$, representing internal cytosine of $5^{\prime}$-CCGG methylation in full CG sites. (iv) Type IVband absent for both enzyme reactions $(0,0)$, representing full methylation in both cytosines ${ }^{11,26}$. The methylation level was represented as follows

$$
\begin{aligned}
\text { Total methylated ratio }= & {[(\mathrm{II}+\mathrm{III}+\mathrm{IV}) /} \\
& (\mathrm{I}+\mathrm{II}+\mathrm{III}+\mathrm{IV})] \times 100 \% .
\end{aligned}
$$

Fully methylated ratio $=[(\mathrm{III}+\mathrm{IV}) /$

$$
(\mathrm{I}+\mathrm{II}+\mathrm{III}+\mathrm{IV})] \times 100 \% \text {. }
$$

Hemi-methylated ratio $=[(\mathrm{II}) /(\mathrm{I}+\mathrm{II}+\mathrm{III}+\mathrm{IV})] \times 100 \%$.

Non-methylated ratio $=[(\mathrm{I}) /(\mathrm{I}+\mathrm{II}+\mathrm{III}+\mathrm{IV})] \times 100 \%$.
The traits of soybean growth were significantly affected by strontium treatment. The growth of soybean was best without $\mathrm{SrCl}_{2}$ stress. The root and stem lengths, dry and fresh weights of root system and aboveground parts were reduced with increase in $\mathrm{SrCl}_{2}$ concentration. The root/shoot ratio increased with increasing $\mathrm{SrCl}_{2}$ concentration, which indicated that the root growth was less affected than aboveground parts under $\mathrm{SrCl}_{2}$ stress. Table 2 lists the significant differences of seven growth traits.

Methylation patterns and the degree of changes among different strontium treatments were detected using 16 pairs of MSAP primers (Figure 1; a pair of selective primers of EcoRI-6 and MspI/HpaII-6). A total, of 167 bands $5^{\prime}$-CCGG-3' site were detected for six treatments. The amplified DNA bands were classified as four types according to the presence or absence of each locus (Table 3). The total ratio of DNA methylation ranged from $19.16 \%$ to $55.09 \%$ in the six treatments. The methylation degree (including fully methylated and hemi-methylated) initially decreased and then increased with increasing $\mathrm{SrCl}_{2}$ concentration. The lowest methylation degree was found at $10 \mathrm{mmol} / 1 \mathrm{SrCl}_{2}$ and the highest methylation degree was found at $0.00 \mathrm{mmol} / 1 \mathrm{SrCl}_{2}$. On the contrary, the degree of non-methylation initially increased and then decreased.

The patterns of methylation among the six treatments were compared to evaluate the changes in DNA methylation status. These patterns can be divided into two types unchanged and changed. Furthermore, these two types can be distinguished into seven sub-types. Unchanged type show that the methylation status was same among the six treatments, which included non-methylation and unchanged methylation patterns. Also, 30.54\% bands of the non-methylated in all treatments and $11.98 \%$ was unchanged among the six treatments. The banding pattern for DNA methylation showing initial decrease and then increase was the highest accounting for $22.75 \%$, followed by a continuous decrease accounting for 


\section{RESEARCH COMMUNICATIONS}

Table 2. Length of stem and root, dry and fresh weight of root and aboveground parts, root/shoot ratio of soybean under different $\mathrm{SrCl}_{2}$ treatments

\begin{tabular}{|c|c|c|c|c|c|c|c|}
\hline $\begin{array}{l}\mathrm{SrCl}_{2} \\
\text { concentration } \\
(\mathrm{mmol} / \mathrm{l})\end{array}$ & $\begin{array}{l}\text { Length of } \\
\text { root }(\%)\end{array}$ & $\begin{array}{l}\text { Length of } \\
\text { shoot }(\%)\end{array}$ & $\begin{array}{c}\text { Fresh weight } \\
\text { of root }(\mathrm{g})\end{array}$ & $\begin{array}{c}\text { Fresh weight of } \\
\text { aboveground } \\
\text { parts }(\mathrm{g})\end{array}$ & $\begin{array}{l}\text { Dry weight of } \\
\operatorname{root}(\mathrm{g})\end{array}$ & $\begin{array}{l}\text { Dry weight of } \\
\text { aboveground } \\
\text { parts }(\mathrm{g})\end{array}$ & $\begin{array}{c}\text { Root/shoot } \\
\text { ratio }(\%)\end{array}$ \\
\hline 0.00 & $23.25 \pm 0.69^{\mathrm{a}}$ & $26.78 \pm 1.78^{\mathrm{a}}$ & $0.83 \pm 0.035^{\mathrm{a}}$ & $1.42 \pm 0.079^{\mathrm{a}}$ & $0.057 \pm 0.004^{\mathrm{a}}$ & $0.157 \pm 0.008^{\mathrm{a}}$ & $0.37 \pm 0.006^{\mathrm{c}}$ \\
\hline 1.00 & $20.45 \pm 1.06^{\mathrm{b}}$ & $21.63 \pm 1.11^{\mathrm{b}}$ & $0.67 \pm 0.045^{b}$ & $1.35 \pm 0.069^{\mathrm{ab}}$ & $0.054 \pm 0.004^{\mathrm{b}}$ & $0.135 \pm 0.008^{b}$ & $0.42 \pm 0.008^{\mathrm{b}}$ \\
\hline 5.00 & $18.50 \pm 0.60^{\mathrm{c}}$ & $20.10 \pm 1.36^{\mathrm{b}}$ & $0.63 \pm 0.055^{\mathrm{b}}$ & $1.28 \pm 0.049^{\mathrm{b}}$ & $0.052 \pm 0.003^{\mathrm{bc}}$ & $0.120 \pm 0.007^{\mathrm{c}}$ & $0.43 \pm 0.002^{b}$ \\
\hline 10.00 & $17.77 \pm 0.35^{\mathrm{c}}$ & $17.98 \pm 0.38^{\mathrm{c}}$ & $0.59 \pm 0.024^{\mathrm{c}}$ & $0.92 \pm 0.013^{c}$ & $0.051 \pm 0.002^{\mathrm{c}}$ & $0.117 \pm 0.012^{\mathrm{c}}$ & $0.44 \pm 0.025^{b}$ \\
\hline 20.00 & $15.45 \pm 0.99^{\mathrm{d}}$ & $7.77 \pm 0.15^{\mathrm{d}}$ & $0.56 \pm 0.018^{c}$ & $0.78 \pm 0.053^{\mathrm{d}}$ & $0.048 \pm 0.002^{\mathrm{c}}$ & $0.096 \pm 0.007^{\mathrm{d}}$ & $0.53 \pm 0.017^{\mathrm{a}}$ \\
\hline 40.00 & $13.03 \pm 0.68^{\mathrm{e}}$ & $1.42 \pm 0.08^{\mathrm{e}}$ & $0.48 \pm 0.015^{\mathrm{d}}$ & $0.75 \pm 0.019^{\mathrm{d}}$ & $0.047 \pm 0.001^{\mathrm{c}}$ & $0.086 \pm 0.004^{\mathrm{d}}$ & $0.54 \pm 0.019^{\mathrm{a}}$ \\
\hline
\end{tabular}

The weight is the means of individual weight. Different letters in the same column show significant difference among different treatments at 0.05 level.

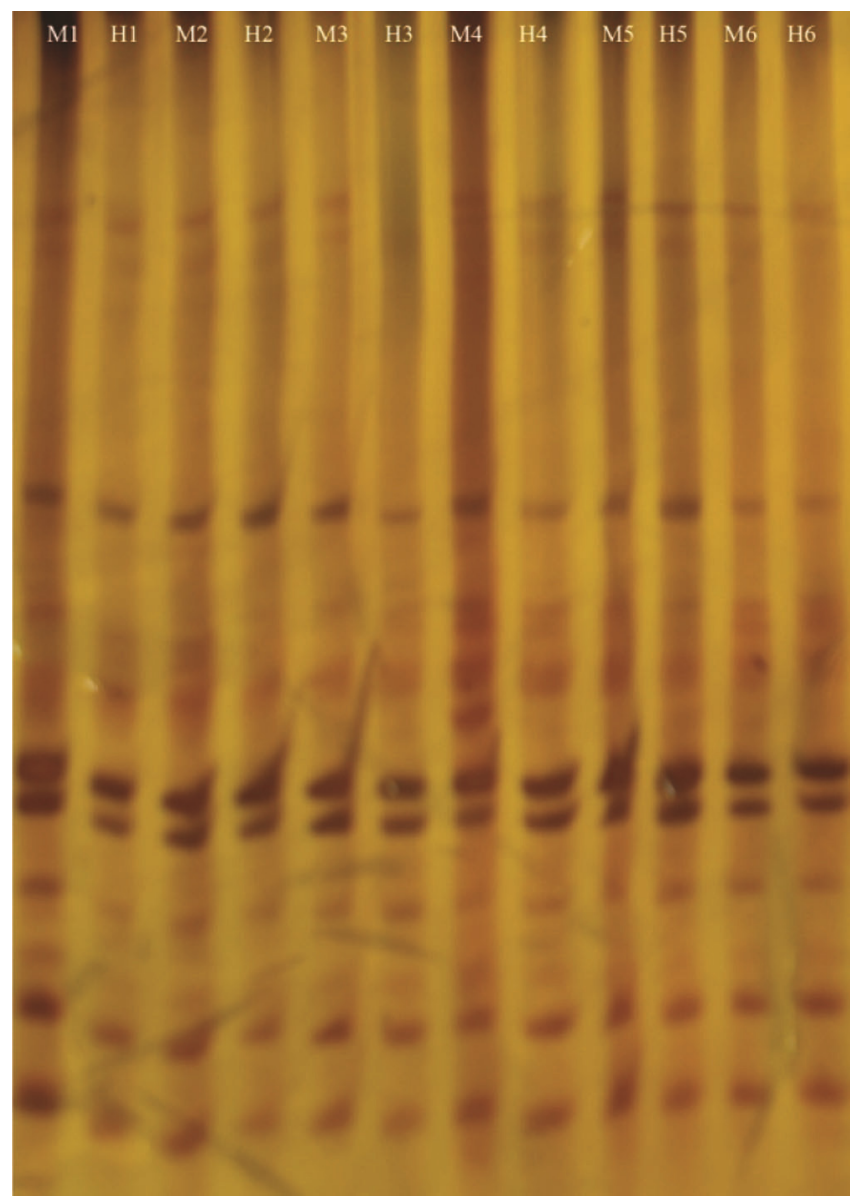

Figure 1. Profiles of methylation-sensitive amplified polymorphism amplification among different $\mathrm{SrCl}_{2}$ treatments using a pair of selective primers of EcoRI-6 and MspI/HpaII-6. M1, M2, M3, M4, M5 and M6 respectively, indicated that $0,1,5,10,20$ and $40 \mathrm{mmol} / 1 \mathrm{SrCl}_{2}$ concentration was digested by EcoR-MspI; H1, H2, H3, H4, H5 and H6 respectively, indicated that $0,1,5,10,20$ and $40 \mathrm{mmol} / 1 \mathrm{SrCl}_{2}$ concentration was digested by EcoRI-HpaII.

$13.17 \%$, continuous increase accounting for $11.38 \%$, and an initial increase and then decrease accounting for $7.78 \%$; the indefinite type methylation pattern was the least $(2.40 \%)$ (Table 4$)$.

Analysis showed that there was a positive correlation between total methylation/fully methylated and the growth traits, including root and stem lengths and weights of root and shoot. There was a negative correlation between hemi-methylated/non-methylated and some growth traits, including root and stem lengths, weights of root system and aboveground parts, and a positive correlation between hemi-methylated/non-methylated and root to shoot ratio (Table 5).

Numerous studies have shown that DNA methylation/ demethylation plays an important role in the gene expression regulation process for adaptation to environmental changes $^{27}$. There have been some studies on the biological effects of strontium ${ }^{5}$. However, there are only a few studies on the correlation between DNA methylation/ demethylation and strontium stress in plants. The MSAP technology has been widely used in the detection of methylation degree and pattern changes in various plants ${ }^{8-11}$. The strontium-induced methylation changes in soybean cultivar Nannong 1138-2 were tracked using the MSAP method. The level of methylation initially decreased and then increased with increasing $\mathrm{Sr}$ concentration. In this study, the soybean methylation level decreased from 0.00 to $10.00 \mathrm{mmol} / 1 \mathrm{SrCl}_{2}$, which might activate the expression of resistance genes, thereby alleviating strontium stress. However, the degree of methylation increased above this $\mathrm{SrCl}_{2}$ concentration, which might lead to the silencing of resistance genes.

Previous studies have indicated that environmental stress can change cytosine methylation patterns of the whole genome ${ }^{28,29}$. The major changes in the patterns of DNA methylation were an initial decrease in methylation followed by an increase with increasing strontium concentration. The second most common alteration of banding patterns for DNA methylation was a decreasing degree in methylation with increasing Sr concentration. These results imply that soybean could alleviate strontium stress by demethylation. However, some genes were methylated with increasing strontium concentration, which likely leads to inhibited expression of such genes.

The correlation between methylation level and growth has been rarely reported under adverse stress conditions. The present study showed that full methylation level was positively correlated with length and weight of roots and 
Table 3. MSAP-based evaluation of chilling-induced changes to methylation measured under different $\mathrm{SrCl}_{2}$ treatments

\begin{tabular}{lcccccc}
\hline & \multicolumn{7}{c}{$\mathrm{SrCl}_{2}$ concentration (mmol/1) } \\
\cline { 2 - 7 } Types and proportions of bands & 0 & 1 & 5 & 10 & 20 & 40 \\
\hline Type-I bands & 75 & 111 & 120 & 135 & 125 & 112 \\
Type-II bands & 12 & 15 & 6 & 3 & 12 & 19 \\
Type-III bands & 44 & 27 & 27 & 15 & 10 & 6 \\
Type-IV bands & 36 & 14 & 14 & 14 & 20 & 30 \\
Total sites & 167 & 167 & 167 & 167 & 167 & 167 \\
Total amplified bands & 131 & 153 & 153 & 153 & 147 & 137 \\
Total methylated bands & 92 & 56 & 47 & 32 & 42 & 55 \\
\% Total methylated bands & 55.09 & 33.53 & 28.14 & 19.16 & 25.15 & 32.93 \\
Fully methylated bands & 80 & 41 & 41 & 29 & 30 & 36 \\
\% Fully methylated bands & 47.90 & 24.55 & 24.55 & 17.37 & 17.96 & 21.56 \\
\% Hemi-methylated bands & 7.19 & 8.98 & 3.59 & 1.80 & 7.19 & 11.38 \\
$\%$ Non-methylated bands & 44.91 & 66.47 & 71.86 & 80.84 & 74.85 & 67.07 \\
\hline
\end{tabular}

Table 4. Different patterns of DNA methylation changes induced by strontium

\begin{tabular}{llcc}
\hline Pattern & \multicolumn{1}{c}{ Methylation level } & Band number & Percentage \\
\hline Unchanged & Non-methylation & 51 & 30.54 \\
& Unchanged of type & 20 & 11.98 \\
Changed & Decreasing trend & 22 & 13.17 \\
& Increasing trend & 19 & 11.38 \\
& First decreasing then increasing & 38 & 22.75 \\
& First increasing then decreasing & 13 & 7.78 \\
& Indefinite type & 4 & 2.40 \\
\hline
\end{tabular}

Table 5. Correlation between methylation level and growth traits

\begin{tabular}{|c|c|c|c|c|c|c|c|c|}
\hline $\begin{array}{l}\text { Methylation } \\
\text { level }\end{array}$ & $\begin{array}{c}\text { Coefficient and } \\
P \text {-value }\end{array}$ & $\begin{array}{l}\text { Length } \\
\text { of root }\end{array}$ & $\begin{array}{l}\text { Length } \\
\text { of shoot }\end{array}$ & $\begin{array}{l}\text { Fresh weight } \\
\text { of root }\end{array}$ & $\begin{array}{c}\text { Fresh weight of } \\
\text { aboveground } \\
\text { parts }\end{array}$ & $\begin{array}{c}\text { Dry weight } \\
\text { of root }\end{array}$ & $\begin{array}{l}\text { Dry weight of } \\
\text { aboveground } \\
\text { parts }\end{array}$ & $\begin{array}{l}\text { Root } / \text { shoot } \\
\text { ratio }\end{array}$ \\
\hline \multirow[t]{2}{*}{ Total methylated } & Correlation coefficient & 0.62 & 0.44 & 0.76 & 0.61 & 0.67 & 0.66 & -0.53 \\
\hline & $P$-value & 0.19 & 0.38 & 0.08 & 0.20 & 0.14 & 0.15 & 0.28 \\
\hline \multirow[t]{2}{*}{ Fully methylated } & Correlation coefficient & 0.76 & 0.63 & 0.88 & 0.71 & 0.80 & 0.79 & -0.70 \\
\hline & $P$-value & 0.08 & 0.18 & 0.02 & 0.12 & 0.06 & 0.06 & 0.12 \\
\hline \multirow[t]{2}{*}{ Hemi-methylated } & Correlation coefficient & -0.27 & -0.46 & -0.17 & -0.14 & -0.21 & -0.23 & 0.40 \\
\hline & $P$-value & 0.61 & 0.36 & 0.75 & 0.79 & 0.69 & 0.66 & 0.43 \\
\hline \multirow[t]{2}{*}{ Non-methylated } & Correlation coefficient & -0.62 & -0.44 & -0.76 & -0.61 & -0.67 & -0.66 & 0.53 \\
\hline & $P$-value & 0.19 & 0.38 & 0.08 & 0.20 & 0.14 & 0.15 & 0.28 \\
\hline
\end{tabular}

aboveground parts under strontium stress. On the contrary, the hemi-methylation and non-methylation degrees were negatively correlated with the length and weight of roots and aboveground parts. These results suggest a view of the relationship between plant growth and methylation under stress.

DNA methylation of soybean exposed to strontium stress was comprehensively analysed in this study. The degree of cytosine methylation initially decreased and then increased with the increasing $\mathrm{Sr}$ concentration.
Strontium stress induced a $57.48 \%$ alteration in the DNA methylation patterns in $5^{\prime}$-CCGG-3' loci. In conclusion, this study provides valuable information for further research focusing on the epigenetic regulation of soybean exposed to strontium stress or other environmental stresses.

1. Kan, U., Koichi, K., Tomotaro, D., Misuzu, W., Hiroyasu, S., Yoshimi, T. and Emi, Y., An overview of boron, lithium, and 


\section{RESEARCH COMMUNICATIONS}

strontium in human health and profiles of these elements in urine of Japanese. Environ. Health Prev. Med., 2007, 12, 231-237.

2. Xie, H. and Ye, Q., Strontium: friend or foe of bone formation? Osteoporosis Int., 2015, 26, 2213-2214.

3. Cohen-Solal, M., Strontium overload and toxicity: impact on renal osteodystrophy. Nephrol. Dial. Transpl., 2002, 17, 30-34.

4. Sreedhar, B., Satya Vani, Ch., Keerthi Devi, D., Sreeram, V. and Basaveswara Rao, M. V., Nucleation controlled in the aggregative growth of strontium carbonate microcrystals. Am. J. Mater. Sci., 2012, 2(5), 142-146.

5. Chen, M., Tang, Y. L., Ao, J. and Wang, D., Effect of strontium on photosynthetic characteristics of oilseed rape seedlings. Russ. J. Plant Physiol., 2012, 59, 772-780.

6. Kamangar, A. and Haddad, R., Effect of water stress and sodium silicate on antioxidative response in different grapevine (Vitis vinifera L.) cultivars. J. Agric. Sci. Technol., 2016, 18, 1859-1870.

7. Sha, A. H., Lin, X. H., Huang, J. B. and Zhang, D. P., Analysis of DNA methylation related to rice adult plant resistance to bacterial blight based on methylation-sensitive AFLP (MSAP) analysis. Mol. Gen. Genomics, 2005, 273, 484-490.

8. Shan, X. H. et al., Analysis of the DNA methylation of maize (Zea mays L.) in response to cold stress based on methylation-sensitive amplified polymorphisms. J. Plant Biol., 2013, 56, 32-38.

9. Tan, M. P., Analysis of DNA methylation of maize in response to osmotic and salt stress based on methylation-sensitive amplified polymorphism. Plant Physiol. Biochem., 2010, 48, 21-26.

10. Keyte, A. L., Percifield, R., Liu, B. and Wendel, J. F., Infraspecific DNA methylation polymorphism in cotton (Gossypium hirsutum L.). J. Hered., 2006, 97, 444-450.

11. Xin, C. H. et al., Analysis of cytosine methylation status in potato by methylation-sensitive amplified polymorphisms under lowtemperature stress. J. Plant Biol., 2015, 58, 383-390.

12. Bonasio, R., Tu, S. and Reinberg, D., Molecular signals of epigenetic states. Science, 2010, 330, 612-616.

13. Choi, C. S. and Sano, H., Abiotic-stress induces demethylation and transcriptional activation of a gene encoding a glycerophosphodiesterase-like protein in tobacco plants. Mol. Genet. Genomics, 2007, 277, 589-600.

14. Heller, G., Zielinski, C. C. and Zöchbauer-Müller, S., Lung cancer: from single-gene methylation to methylome profiling. Cancer Metastasis Rev., 2010, 29(1), 95-107.

15. Jaligot, E., Beuléand, T. and Rival, A., Methylation-sensitive RFLPs: characterization of two oil palm markers showing somaclonal variation-associated polymorphism. Theor. Appl. Genet., 2002, 104, 1263-1269.

16. Capuano, F., Mulleder, M., Kok, R., Blom, H. J. and Ralser, M., Cytosine DNA methylation is found in Drosophila melanogaster but absent in Saccharomyces cerevisiae, Schizosaccharomyces pombe, and other yeast species. Anal. Chem., 2014, 86, 36973702 .

17. Cicatelli, A., Todeschini, V., Lingua, G., Biondi, S., Torrigiani, P. and Castiglione, S., Epigenetic control of heavy metal stress response in mycorrhizal versus non-mycorrhizal poplar plants. Environ. Sci. Pollut. Res. Int., 2014, 21, 1723-1737.

18. Tang, X. M., Tao, X., Wang, Y., Ma, D. W., Li, D., Yang, H. and Ma, X. R., Analysis of DNA methylation of perennial ryegrass under drought using the methylation sensitive amplification polymorphism (MSAP) technique. Mol. Genet. Genomics, 2014, 289, 1075-1084.

19. Cervera, M. T., Ruiz-Garcia, L. and Martinez-Zapater, J., Analysis of DNA methylation in Arabidopsis thaliana based on methylationsensitive AFLP markers. Mol. Genet. Genomics, 2002, 268, $543-552$.

20. Lam, H. M. et al., Resequencing of 31 wild and cultivated soybean genomes identifies patterns of genetic diversity and selection. Nature Genet., 2010, 42, 1053-1059.
21. Wójciak-Kosior, M. et al., The stimulatory effect of strontium ions on phytoestrogens content in Glycine $\max (\mathrm{L}$.) Merr. Molecules, 2016, 21; doi:10.3390/ molecules21010090.

22. Xiong, D. J., Zhao, T. J. and Gai, J. Y., Parental analysis of soybean cultivars released in China. Sci. Agric. Sin., 2008, 41(9), 2589-2598 (in Chinese).

23. Fehr, W. R., Caviness, C. E., Burmood, D. T. and Pennington, J. S., Stage of development descriptions for soybeans, Glycine max (L.) Merrill. Crop Sci., 1971, 11(6), 929-931.

24. Saghai-Maroof, M. A., Soliman, K. M., Jorgensen, R. A. and Allard, R. W., Ribosomal DNA spacer-length polymorphisms in barley: mendelian inheritance, chromosomal location, and population dynamics. Proc. Natl. Acad. Sci. USA, 1984, 81(24), 8014 8018 .

25. Xiong, L. Z., Xu, C. G., Saghai-Maroof, M. A. and Zhang, Q. F., Patterns of cytosine methylation in an elite rice hybrid and its parental lines by a methylation-sensitive amplification polymorphism technique. Mol. Gen. Genet., 1999, 261, 439-446.

26. Wang, W. S. et al., Drought-induced site-specific DNA methylation and its association with drought tolerance in rice (Oryza sativa L.) J. Exp. Bot., 2011, 62(6), 1951-1960.

27. Jaroslav, F. and Aleš, K., How to interpret methylation sensitive amplified polymorphism (MSAP) profiles? BMC Genetics, 2014; doi:10.1186/1471-2156-15-2.

28. Cao, D. H. et al., Methylation sensitive amplified polymorphism (MSAP) reveals that alkali stress triggers more DNA hypomethylation levels in cotton (Gossypium hirsutum L.) roots than salt stress. Afr. J. Biotechnol., 2011, 10, 18971-18980.

29. Zhao, Y. L., Yu, S. X., Ye, W. W., Wang, H. M., Wang, J. J. and Fang, X., Study on DNA cytosine methylation of cotton (Gossypium hirsutum L.) genome and its implication for salt tolerance. Agric. Sci. China, 2010, 9, 783-791.

ACKNOWLEDGEMENTS. This study was supported by the Open fund of Key Laboratory for Crop Genetics and Germplasm Enhancement (ZW201812), National Natural Science Foundation of China (31871711), Anhui Provincial College Program for Natural Science, the Science and Technology Program of Sichuan Province (2017NZZJ020; 2019YJ0679), the Anhui Provincial Program for Natural Science (1608085MC69) and Program of Stable Talents of Anhui Science and Technology University.

Received 24 November 2017; revised accepted 9 May 2019

doi: $10.18520 / \mathrm{cs} / \mathrm{v} 117 / \mathrm{i} 3 / 486-491$ 